\title{
THE CENTRAL PUOLANKA GROUP - A PRECAMBRIAN REGRESSIVE METASEDIMENTARY SEQUENCE IN NORTHERN FINLAND
}

\author{
KAUKO LAAJOKI
}

LAAJOKI, KAUKO, 1986: The Central Puolanka Group - a Precambrian regressive metasedimentary sequence in northern Finland. Bull. Geol. Soc. Finland 58, Part 1, 179-193.

Quite recently, an amphibolite-facies metasedimentary sequence at least $2500 \mathrm{~m}$ thick, named the Central Puolanka Group (CPG) was recognized underlying the traditional Jatuli-type sequences at the western margin of the Early Proterozoic Kainuu Schist Belt in Central Puolanka. To the west, towards the Archaean basement of the Pudasjärvi - Vaala area, the primary sedimentary and stratigraphic features of the metasediments have been destroyed by severe metamorphism and migmatization to such a degree that the lowermost and the western parts of the CPG, have inverted into gneisses, called collectively the West Puolanka Paragneiss (WPP), within which it is no longer possible to map the rocks in terms of paleosedimentology and whose sedimentation basement has not yet been found. The zone between the CPG proper and the WPP is underlain by the Kettukangas paragneiss which may locally show turbidite features and which grades stratigraphically upwards into the CPG.

The CPG itself consists of three formations called, from the oldest to the youngest, the Puolankajärvi Formation $(\mathrm{PjF})$, the Akanvaara Formation $(\mathrm{AvF})$ and the Pärekangas Formation $(\mathrm{PkF})$. In terms of primary sediments, the lower and middle part of the $\mathrm{PjF}$ is made up of turbidite sands and muds deposited either at the outer parts of a shelf or in a deep water fan of an ancient continental margin. The upper part consists of cross-bedded or rippled silts and fine sands with interbeds of cross-bedded sands whose amount increases upwards towards the AvF. The latter is made up almost entirely of cross-bedded sands deposited either in an inner shelf or in deltaic environments. They are overlain abruptly but conformably by the dominant muds and silts of the $\mathrm{PkF}$ showing evidence of a tidal environment. This regressive CPG sequence is overlain unconformably by the fluvial gravels and sands of the first of the transgressive Jatuli-type sequences which form the bulk of the Kainuu Schist Belt.

The CPG can be mapped as a coherent lithostratigraphic unit from Puolanka to Paltamo. The preliminary mapping of the paragneiss areas west of the Kainuu Schist Belt indicates, however, that the sediments of this sequence once covered a wide area which extended from Puolanka to at least Koillismaa in the north and to Otanmäki, at least, in the south and they may represent the same sedimentaryvolcanic cycle which produced the Middle and Upper Lapponian sediments and volcanics of Lapland.

Key words: Precambrian sedimentology and stratigraphy, metaturbidites, Central Puolanka Group, Puolanka, Kainuu, Finland.

Kauko Laajoki: Department of Geology, University of Oulu, Linnanmaa, SF-90570 Oulu, Finland. 


\section{Introduction}

Since 1966 the northern end of the Precambrian Kainuu Schist Belt at Puolanka has been a target of intensive geological research, first by the Prospecting Department of the Geological Survey of Finland and then by the Department of Geology of the University of Oulu. From a scientific point of view, one of the most important results of these investigations has been the establishment of the presence of a metasedimentary sequence at least $2500 \mathrm{~m}$ thick underlying the traditional Jatulian (Lower Proterozoic) formations in the area between the Kainuu Schist Belt proper in the east and the paragneisses and gneisses of the $\mathrm{Pu}$ dasjärvi - Vaala area in the west (Fig. 1).

This paper aims at giving a brief stratigraphic and paleosedimentological summary of these metasedimentary rocks grouped lithostratigraphically into the so-called Central Puolanka Group (CPG). The lowermost parts of the group and the associated paragneisses have been described in Finnish by Korkiakoski $(1981,1982)$ and Taikina-aho (1982), respectively. The reader interested in the Precambrian geology of Puolanka in general is referred to the earlier papers (Laajoki 1973, 1980 a, Laajoki and Saikkonen 1977) and to a recent review (Laajoki in prep.) and the references in it.

\section{The gross geological setting of the CPG}

The CPG is defined as containing the metasediments and associated metavolcanics in the western part of the Kainuu Schist Belt forming a sequence older than the Jatuli-type quartzite sequences and showing primary sedimentary features sufficient for lithostratigraphic and paleosedimentological work. It is bounded by an intra-Karelian unconformity in the east while in the west it grades with an increasing degree of metamorphism and migmatization into paragneisses and migmatic gneisses called collectively the West Puolanka Paragneiss (WPP) (Fig. 2).
The WPP is migmatized and intruded abundantly by Karelidic granites and pegmatites about 1900-1800 Ma old. Its gneisses show, however, here and there, weak relict features that prove that they are mostly, if not all, metamorphic derivatives of the same sequence which deposited the CPG. The deformation within the WPP is so complicated and the exposures so scanty that it is not possible to unravel the internal stratigraphy nor to make any larger sedimentological analysis. Neither has it been possible to locate the sedimentary basement of these paragneisses but quite probably they were deposited on the Archaean rocks visible in the Pudasjärvi - Vaala area. In other words, the CPG represents the upper, relatively well preserved part of the sedimentary-volcanic sequence whose lower parts were metamorphosed to gneisses (WPP) west of the Kainuu Schist Belt. Consequently, the CPG can provide us with only a partial record of the history of this oldest, Karelian sedimentary cycle in western Kainuu.

\section{The metamorphism and structure of the CPG}

The major part of the CPG has undergone amphibolite facies metamorphism as verified by abundant garnet, staurolite and sillimanite in its western metapelites (Laajoki et al. 1982). The northeastern parts were metamorphosed under the conditions of green schist facies. The whole group has gone through at least three deformation phases which turned it into a near-vertical position or slightly overturned to the east. In spite of the many fold phases, the rocks form a continuous N-S trending east-facing sequence in Central Puolanka representing the eastern flank of a south plunging fold called the Puolanka anticline. The western, poorly exposed, flank of this fold is highly deformed and was possibly cut off tectonically or at least greatly transposed. The anticline closes itself in the surroundings of Kongasjärvi in the south. The degree of metamorphism allows sedimentological work only in the eastern part of this fold. 


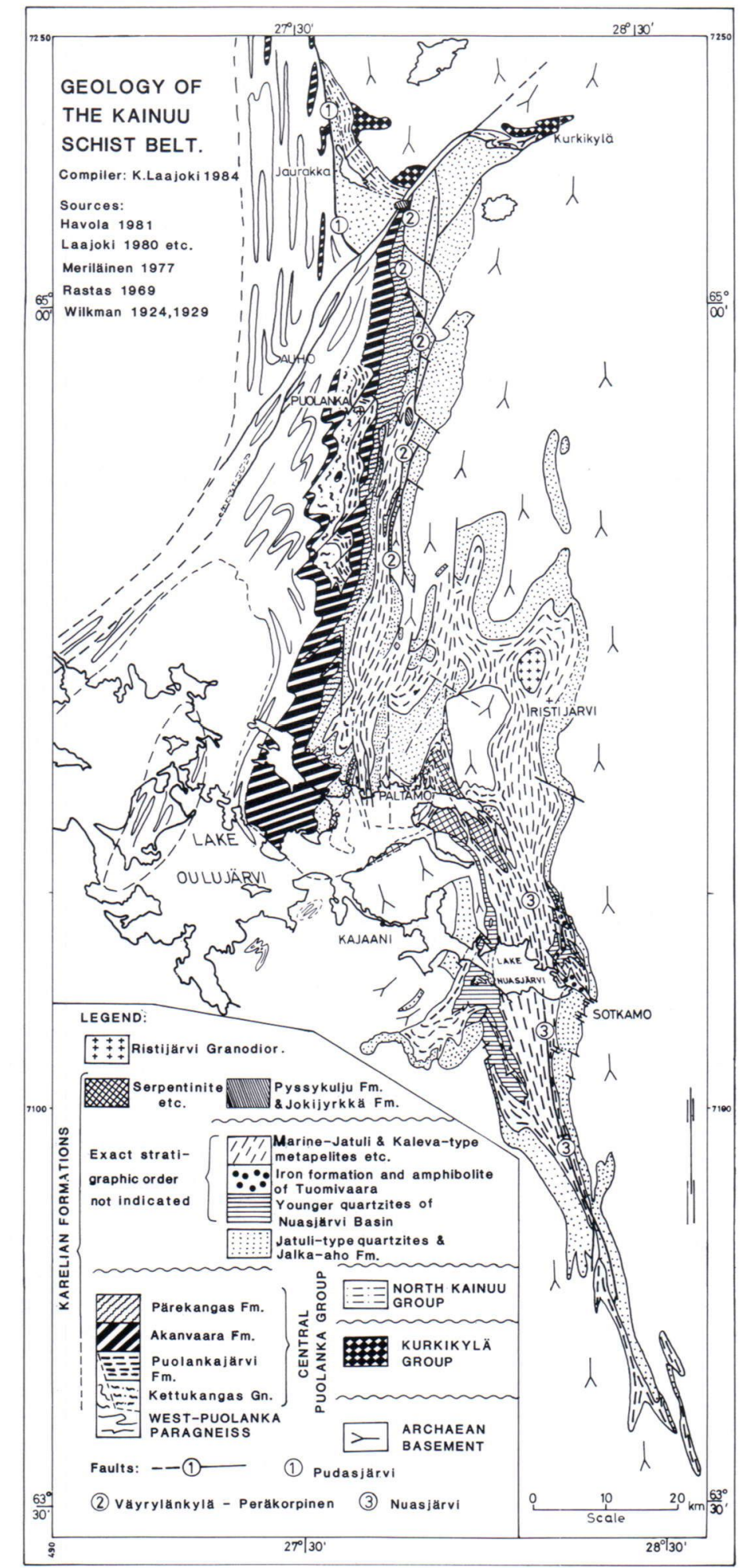

Fig. 1. Simplified geological map of the Kainuu Schist Belt. Note the sources given on the right upper corner of the map. 


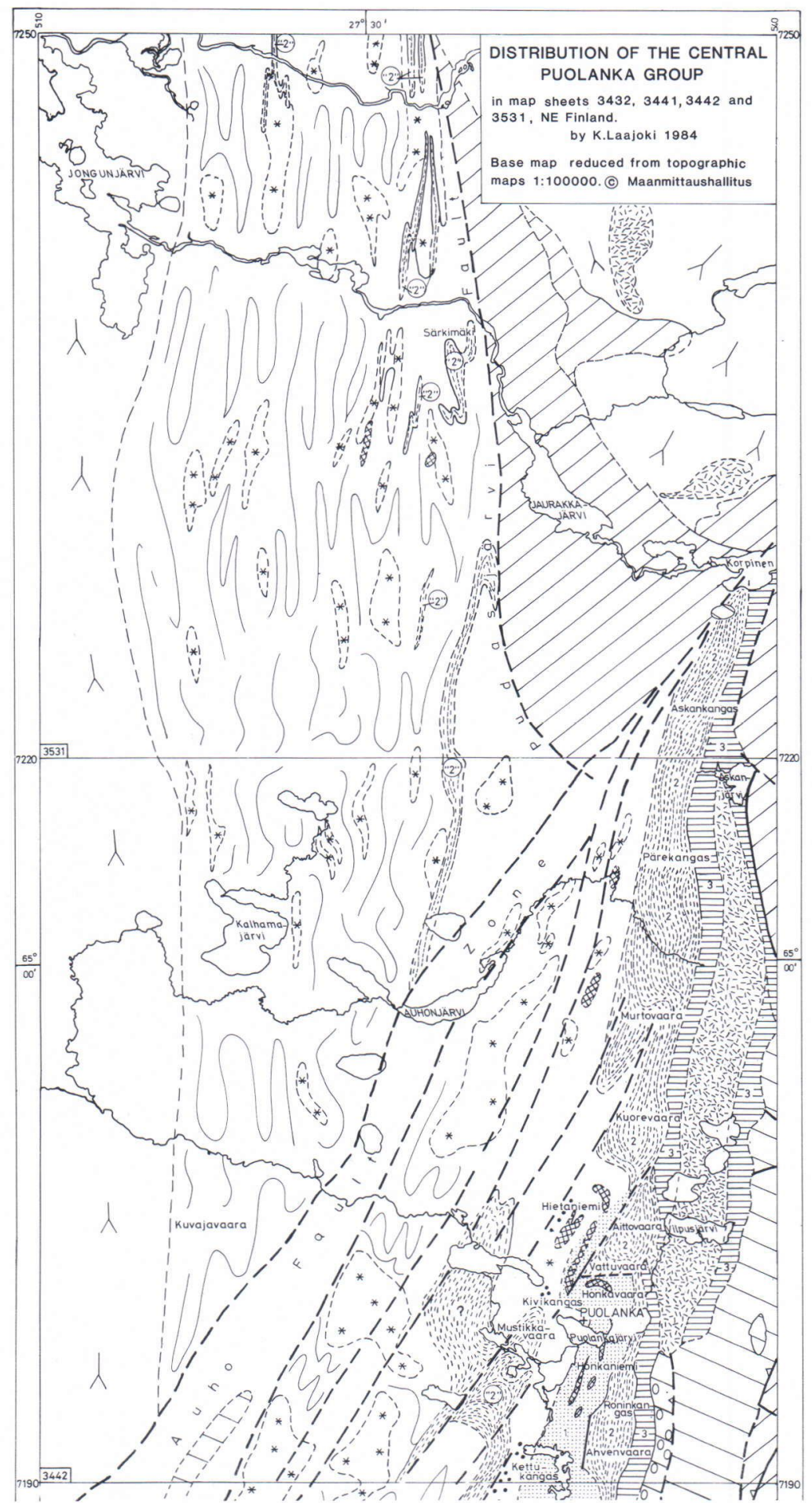




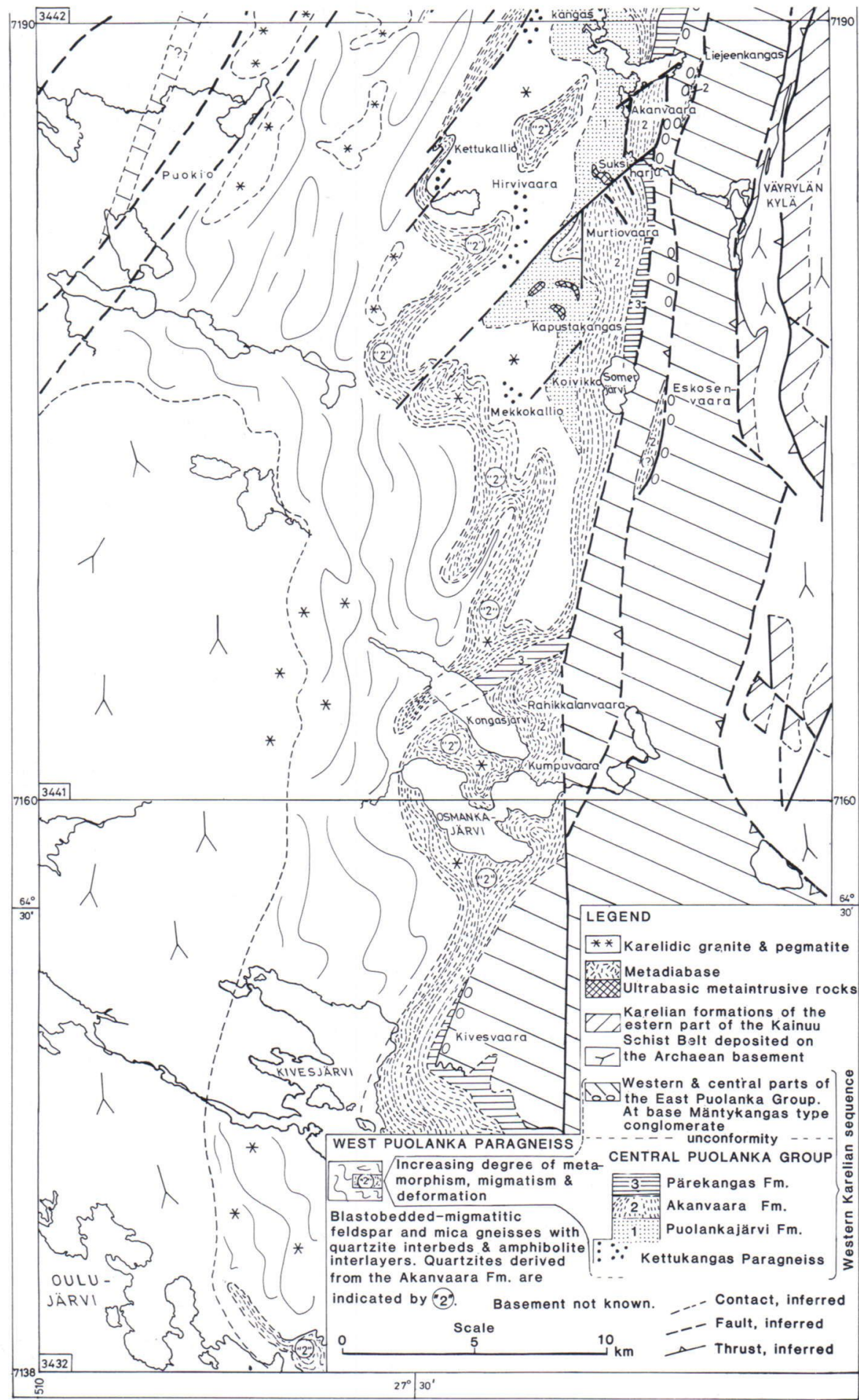

Fig. 2. Simplified geological map of the western part of the Kainuu Schist Belt showing the distribution of the CPG rocks. 


\section{The lithostratigraphy and paleosedimentology of the CPG}

The CPG consists of three metasediment formations which are called, from the oldest upwards, the Puolankajärvi Formation $(\mathrm{PjF})$, the Akanvaara Formation (AvF) and the Pärekangas Formation $(\mathrm{PkF})$. Table 1 summaries the main lithostratigraphic features of the $\mathrm{CPG}$ as well as the paleosedimentological interpretations. It should be noted that the lowermost part of the primary sedimentary sequence, which is of unknown thickness, was »eaten» by metamorphism and that the Kettukangas gneiss represents a transition towards more highly metamorphic gneisses of the WPP stratigraphically underlying the CPG. In the following discussion metamorphic rock names are used with reference to the lithostratigraphy while the paleosedimentological interpretation employs sediment names based on approximate grain sizes.

\section{The lower contact zone (The Kettukangas Paragneiss)}

The border zone between the CPG and the paragneisses is extremely poor in exposures and so the relationship between these two lithologies is poorly known. However, the nearest few exposures west of the $\mathrm{PjF}$ are always banded or blastobedded feldspar-rich or pelitic gneisses which may still show locally rather well-preserved

Table 1. Lithostratigraphy and palaeosedimentological interpretations of the Central Puolanka Group.

\begin{tabular}{|c|c|c|c|}
\hline Group & Formation & Lithology & Interpretation \\
\hline $\begin{array}{l}\text { East } \\
\text { Puolanka }\end{array}$ & Mäntykangas & $\begin{array}{l}\text { Quartzite } \\
\text { Conglomerate with quartz vein, AvF, } \\
\text { and PkF phenoclasts }\end{array}$ & $\begin{array}{l}\text { Shelf Sands } \\
\text { Fluvial gravels }\end{array}$ \\
\hline & 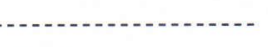 & Unconformity & Erosion and ? block movements \\
\hline \multirow[t]{6}{*}{$\begin{array}{l}\text { Central } \\
\text { Puolanka }\end{array}$} & $\begin{array}{l}\text { Pärekangas } \\
\text { (at least } 500 \mathrm{~m})\end{array}$ & $\begin{array}{l}\text { Wavy bedded or graded phyllites with } \\
\text { cross-bedded quartzite interbeds }\end{array}$ & $\begin{array}{l}\text { Tidal muds and silts and } \\
\text { beach sands }\end{array}$ \\
\hline & $\begin{array}{l}\text { Akanvaara } \\
\text { (at least } 800 \mathrm{~m} \text { ) }\end{array}$ & $\begin{array}{l}\text { Cross-bedded sericite-quartzite and } \\
\text { orthoquartzite (upper } 200-300 \mathrm{~m} \text { ) } \\
\text { Cross-bedded feldspar quartzite and } \\
\text { arkosite with minor pelitic interbeds }\end{array}$ & $\begin{array}{l}\text { Shallow-water sands } \\
\text { Shelf and (?) deltaic } \\
\text { sands and silts }\end{array}$ \\
\hline & $\begin{array}{l}\text { Puolankajärvi } \\
\text { (at least } 830 \mathrm{~m} \text { ) }\end{array}$ & $\begin{array}{l}\text { Mica-schist (highly deformed facies } 3 \text { ?) } \\
\text { with cross-bedded quartzite interbeds } \\
\text { (facies } 4 \text { ). }\end{array}$ & $\begin{array}{l}\text { Transition to shallow water } \\
\text { environment (outer-inner shelf) }\end{array}$ \\
\hline & & $\begin{array}{l}\text { Alternating members of graded } \\
\text { staurolite mica schist (facies 2) and } \\
\text { cross-bedded or rippled feld- } \\
\text { spar-rich mica schist (facies 3) }\end{array}$ & $\begin{array}{l}\text { Transition from turbiditic to } \\
\text { shallow water environment } \\
\text { (outer shelf) }\end{array}$ \\
\hline & & $\begin{array}{l}\text { Alternating members of graded stauro- } \\
\text { lite mica schist (facies } 2 \text { ) and graded } \\
\text { or massive arkosite (facies } 1 \text { ) }\end{array}$ & $\begin{array}{l}\text { Turbidite sands and associated } \\
\text { silts and muds (deep-water fan } \\
\text { or the distal rim of the shelf) }\end{array}$ \\
\hline & -- & Metamorphic and tectonic contact & \\
\hline $\begin{array}{l}\text { Transition } \\
\text { zone }\end{array}$ & $\begin{array}{l}\text { Kettukangas } \\
\text { Paragneiss } \\
\text { (at least } 500 \mathrm{~m} \text { ) }\end{array}$ & $\begin{array}{l}\text { Thin bedded }(<20 \mathrm{~cm}) \text { arkositic para- } \\
\text { gneisses and mica schist interbeds } \\
\text { both with local relict graded bedding } \\
\text { (highly metamorphosed facies } 1 \text { and } 2 \\
\text { of the PJF, respectively) }\end{array}$ & $\begin{array}{l}\text { „Distal» sandy and muddy } \\
\text { turbidites (A metamorphic } \\
\text { transition zone from the CPG } \\
\text { to SW-PGC) }\end{array}$ \\
\hline Southwest & & Banded or migmatitic feldspar and mica & Highly metamorphic derivatives \\
\hline Paragneiss & & gneisses with quartzite interformations & mostly of the CPG \\
\hline Complex & & $\begin{array}{l}\text { Intruded and migmatized by Karelidic } \\
\text { granites and pegmatites }\end{array}$ & \\
\hline
\end{tabular}


primary sedimentary structures. Thus they represent an intermediate form between the gneisses of the WPP without distinctive primary features and the $\mathrm{PjF}$ with rather well-preserved sedimentary structures.

These gneisses are mapped collectively as the Kettukangas Paragneiss (KeP). Most of them represent stratigraphically lower units than the $\mathrm{PjF}$, but in the north where the metamorphic isogrades cut the lithostratigraphic boundaries at a rather high angle the KeP may in fact represent the lateral, more metamorphosed extension of the $\mathrm{PjF}$.

The KeP is exposed at the following places, listed from the south to the north; Mekkokallio, Hirvivaara, Kettukangas, the type locality, Kivikangas, and Hietaniemi.

At Kettukangas, a $240 \mathrm{~m}$ thick section of gneisses inverted into a vertical position is exposed (Taikina-aho 1982). The prevailing rock is arkositic paragneiss with minor mica-rich bands or intermembers intruded by Karelidic pegmatites. It can be seen locally that the former represents arkositic meta-turbidites in which Bouma A and E divisions can still be determined (Fig. 3). The thickness of the individual beds is about 10-20 $\mathrm{cm}$ or less, of which the A division takes the bulk. The pelitic members are also locally graded. The formation seems to be characterized primarily by a thin-bedded arkositic paragneiss still showing distinct bedding, but in which the graded structure is no longer visible. There, where metamorphism went still further, a distinct secondary boundary developed between the lower arkositic (A division) and the pelitic upper (E division) parts with the consequence that a banded gneiss with separate feldspar-rich and mica-rich bands developed (Fig. 4).

Although the relics of the primary structures are rather scanty, it can be concluded that the $\mathrm{KeP}$ represents a turbidite unit dominated by arkositic metasediments whose individual beds are mostly only some centimeters or $10-20 \mathrm{~cm}$ thick.

\section{The Puolankajärvi Formation (PjF)}

The Puolankajärvi Formation (PjF) previously called the Staurolite-Mica-Schist Formation is distinguished from the gneisses in the west by the appearance of abundant staurolite and garnet in its pelitic members and the better preserved primary structures. The dip of the bedding is mostly almost vertical except in the Suksiharju area where the beds are overturned slightly towards the north-east. The $\mathrm{PjF}$ is unevenly exposed, which, together with folding, makes thickness estimates difficult. However, the thickness is at least $1500 \mathrm{~m}$ and $800 \mathrm{~m}$ in the south and north, respectively. The following description is based on the studies by Korkiakoski (1981, 1982) and the author (Laajoki et al. 1982, Laajoki, in prep., Laajoki \& Korkiakoski, in prep.).

The lower part of the PjF in Honkaniemi begins with an approximately $120 \mathrm{~m}$ thick, pervasively schistose staurolite mica schist unit into whose upper part a differentiated metagabbro-amphibole-rock body has been intruded. Then follows a $90 \mathrm{~m}$ thick sequence of arkositic metasediments consisting mainly of graded or massive arkosite beds $\mathrm{n} \times 10 \mathrm{~cm}$ in thickness with thin staurolite mica schist members showing graded bedding. This part is again overlain by a pelitic unit about $130 \mathrm{~m}$ thick whose lower part consists of gradedbedded staurolite mica schist with a few massive or graded arkosite beds and the upper of nonporphyroblastic graded-bedded mica schist. The pelitic lithology contains thin sandstone veins often deformed in a complicated way as at Honkavaara and Honkaniemi.

In the south, the lowermost parts of the $\mathrm{PjF}$ are not exposed and only one exposure in Koivikko shows rocks of the same kind as described above. Here a rather thick sequence of intermembers of massive or graded arkosite and graded-bedded staurolite mica schist exists. The sequence is, however, intensely faulted and only partly exposed, but it seems to be at least $400 \mathrm{~m}$ thick.

The middle southern part of the $\mathrm{PjF}$ is exposed at Kapustakangas and Suksiharju. No con- 


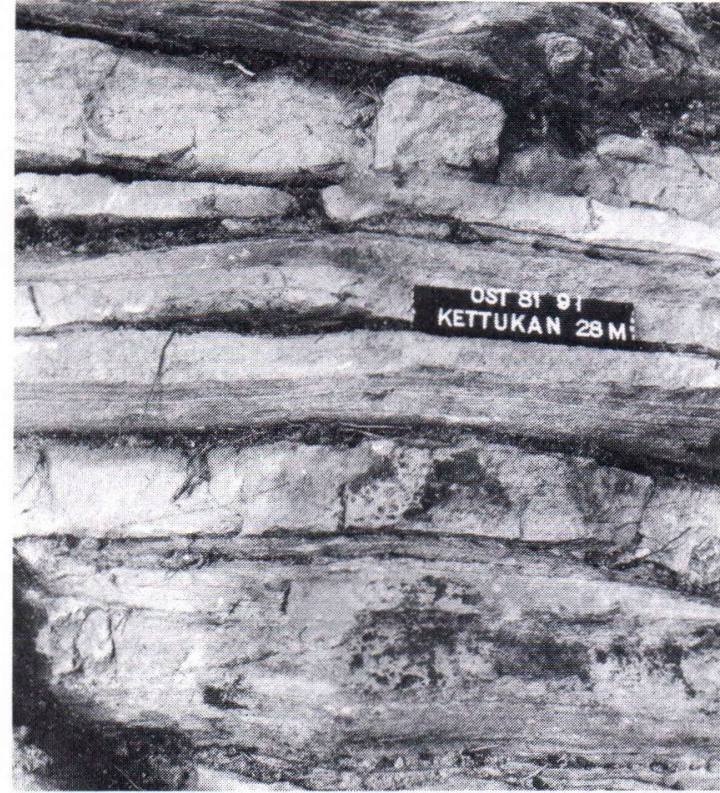

Fig. 3. Arkositic paragneiss at Kettukangas showing alternating massive sand (Bouma A-division) and schistose pelitic (deformed Bouma D-E-division) bands. Top downwards. Beds dip vertically. Photo O. Taikina-aho. The length of the label is $16,5 \mathrm{~cm}$.

tinuous stratigraphic sections can be established. At Kapustakangas a section $200 \mathrm{~m}$ thick can be measured, while in other parts only about $10 \%$ or even less of the total thickness of the $\mathrm{PjF}$ is exposed. The small exposures are, however, distributed in such a regular way that together with the constant north-eastern top directions they indicate a section of the $\mathrm{PjF}$ (at least $1000 \mathrm{~m}$ thick) which consists of alterating members of regularly graded thin-bedded staurolite mica schist or andalusitezed staurolite mica schist, which starts the exposed sequence, and cross-bedded or rippled feldspar-rich mica schist (metasemipelite).

It is impossible to determine the thicknesses of the individual members exactly, except at Kapustakangas, where the lowermost metasemipelite member is at least $140 \mathrm{~m}$ thick. In other places individual members are at least some tens of metres thick, but may exceed a hundred meters.

The major, upper part of the $\mathrm{PjF}$ in the north consists of cross-bedded or rippled metasemipelite

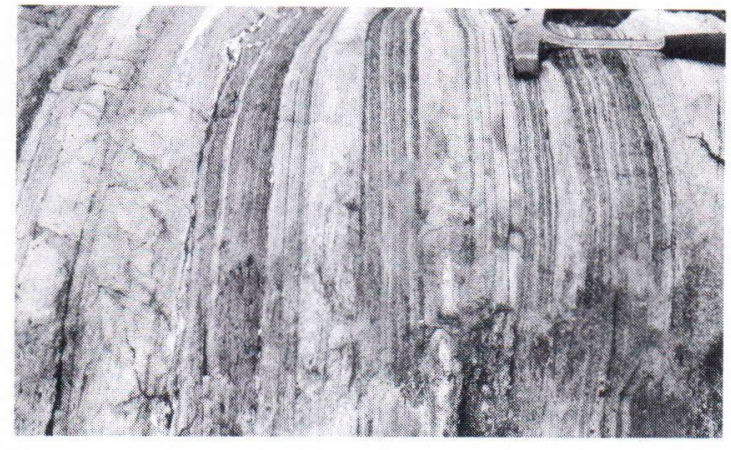

Fig. 4. A typical thin-bedded, vertically dipping arkositic paragneiss with mica schist interbeds of the KeP at Hietaniemi. Photo K. Laajoki.

at least $400-500 \mathrm{~m}$ thick. In the very uppermost parts interbeds of cross-bedded arkosites or feldspar quartzites appear. The abundance and thickness of these beds increase upwards and the $\mathrm{PjF}$ changes rather abruptly via an interbedded contact zone to the Akanvaara Formation. The upper part of the $\mathrm{PjF}$ is not exposed in the south with the exception of the very uppermost parts in Huosiuslampi, where the above described gradual change can be demonstrated, in spite of the fact that here the beds are intensely refolded and now form a complicated interference pattern.

Within the PjF four main primary sedimentary facies can be defined (Laajoki and Korkiakoski, in prep.). These are numbered from 1 to 4 in the order they appear in the stratigraphic column and named after their diagnostic sedimentary structure(s) and approximately primary grain size. Of these facies 2 and 3 contain many subfacies and there is some gradation between 1 and 2 .

Facies 1: Graded or massive sands: This facies consists of light brown sandstone beds which are mostly some tens of centimetres sometimes up to $1 \mathrm{~m}$ thick (Figs. 5 \& 6). They usually occur either as single or amalgamated beds. At their lower contacts flame or load cast structures occur, while the upper contact is mostly planar. The beds are predominantly massive, but many of the thickest ones show faint graded structures at their base. A very few beds show faint parallel laminations in their upper parts, overlain sometimes by 


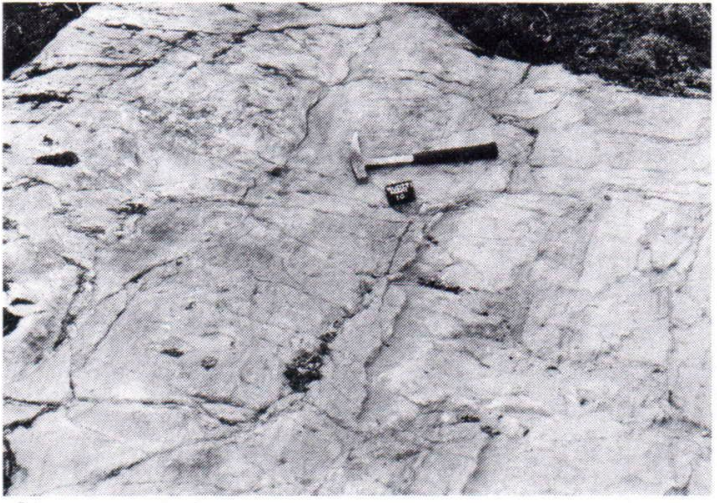

Fig. 5. Amalgameted fasies 1 metaturbidite beds at Koivikko, Nuottimäki. Top to the left. Individual beds are about $40-70 \mathrm{~cm}$ thick. Photo K. Laajoki.

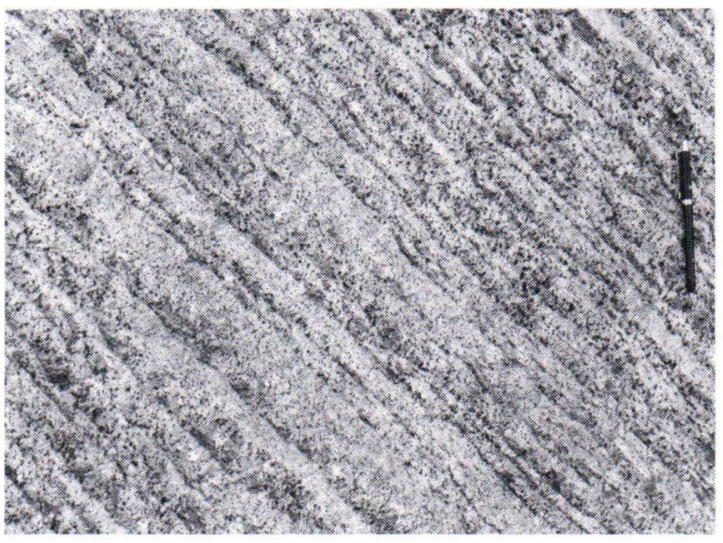

Fig. 7. A typical graded bedded fasies 2 staurolite mica schist at Suksiharju. Top to the lower left corner. Photo K. Laajoki.

wavy laminations. It is not, however, always possible to determine whether this lamination is primary (B unit) or due to the schistosity parallel to the bedding. The grain size of the sandstone varies from coarse sand, or very rarely pebbly sand (maximum ø $7 \mathrm{~mm}$ ) at the base to sand at the top. Some of the thickest beds in Koivikko contain a thin muddy upper seam which is now sericite schist. No sole structures has been identified, which is due to the fact that the bases of the beds are not visible and that the bed contacts are mostly sheared.

The rock consists of quartz and plagioclase

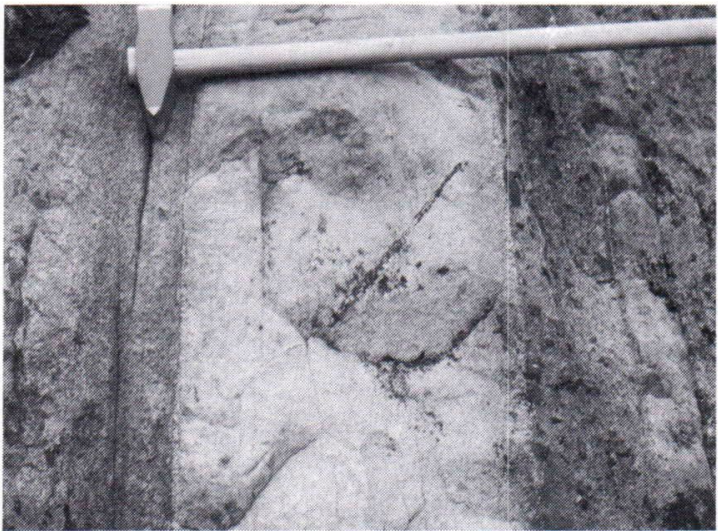

Fig. 6. A close up of a solitary massive arkosite bed (fasies 1 sand) in staurolite schist at Honkavaara. Photo K. Laajoki.

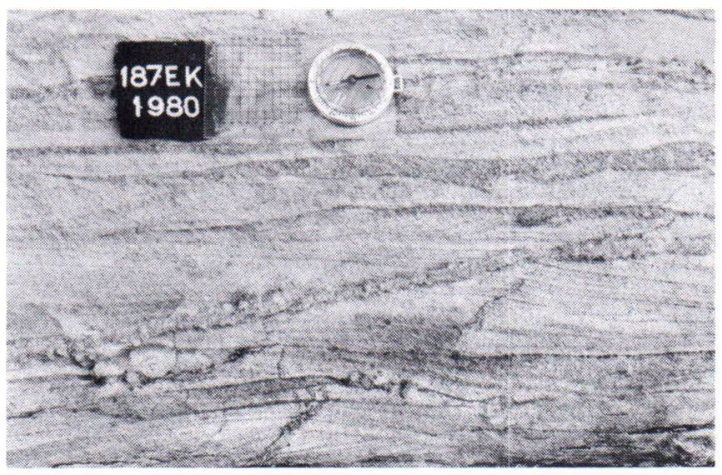

Fig. 8. A typical fasies 3 metasemipelite showing cross bedding whose troughs are draped by pelitic material. The label is $6 \times 6 \mathrm{~cm}$. Photo $\mathrm{K}$. Laajoki.

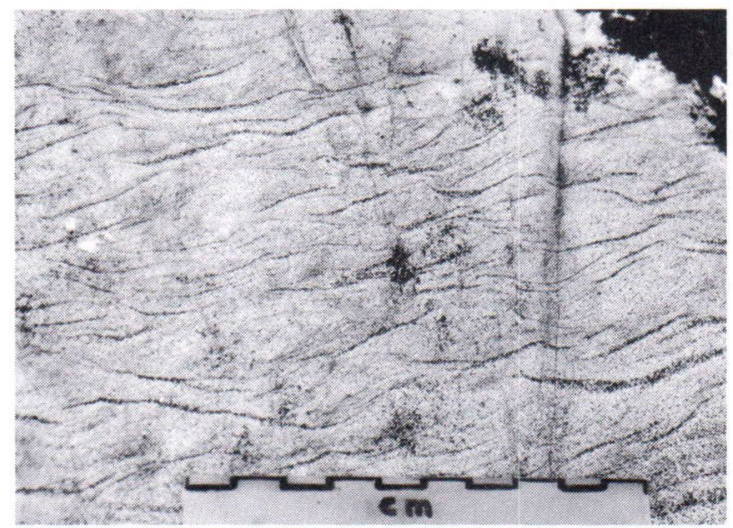

Fig. 9. Ripple cross-laminated sands of fasies 3 at Suksiharju. Note the ripple troughs draped by pelitic material. Photo K. Laajoki. 
with minor biotite and muscovite and its texture is mostly completely granoblastic or, in rare cases, shows a faint blastoclastic texture. As a whole the facies is composed of rather clean or »washed» quartz-plagioclase sand.

Without doubt, this facies represents sands deposited by high density turbidity currents. The massive and graded arkositic sand beds are A turbidites and at least some of those with laminated upper divisions are $\mathrm{AB}$ or $\mathrm{ABC}$ turbidites. The rare muddy upper drapes may represent sediments deposited from suspension from the waining tail of the current or from a separate flow.

Facies 2: Graded bedded muddy sands: This facies is characterized by beautifully graded bedded mica schists whose primary grain size is impossible to determine with confidence due to metamorphic recrystallization. The graded strata are usually only $0.5-10 \mathrm{~cm}$ thick and their lower and middle parts consist of feldspar- and quartzrich sand or silt, while the upper parts were originally silty or muddy as indicated by their present richness in micas, staurolite/andalusite and garnet (Fig. 7). In general, the sands comprise about half or even more of the thickness of a graded stratum. Some of the beds start with wavy laminations, which may be climbing ripples and some with small scale cross-lamination. The features above were described from the mica schists containing abundant porphyroblasts of garnet and staurolite/andalusite. There also occur, however, non-porphyroblastic mica schists showing graded bedding. On the basis of their present mineral content these could be classified into a facies of their own, but because their sedimentary structures are identical with the porphyroblastic type they are included in this facies. However, no marks on the wavy lamination or ripples have detected in them.

Although it might be that this facies also originated from turbidity currents, to specify details is difficult. If we apply the conventional turbidite terminology, the dominant graded rock type should be named $\mathrm{A}-\mathrm{E}$. Because the rocks are so highly metamorphosed it is impossible to take a closer standpoint as to their origin, especially as one cannot say whether the upper muddy parts of the graded units really represent Bouma's E division or whether they, or a part of them, represent separate sedimentation units of their own. In part, this facies seems to counterpart Mutti's and Ricci Lucchi's (1978) pelitic arenaceous facies II (facies E). However, no distinct separation, commonly visible in this facies, between the sandy and muddy parts can be detected in the Puolanka rocks. The $\mathrm{A} \rightarrow \mathrm{E}$ turbidites of Walker (1967) and Henderson (1972, p. 894) may be closer to facies 2 .

Facies 3: Cross-bedded or rippled fine sands: The facies 2 is interbedded with or overlain by feldspar-rich metasemipelites containing only a few if no porphyroblasts. These facies 3 rocks show an almost ubiquitous cross-bedding which is mostly of the trough type, but planar crossbedding is also encountered (Fig. 8). The set thickness is mostly $5 \mathrm{~cm}-\mathrm{n} \times 10 \mathrm{~cm}$ and some of the sets may show internal organization in such a way that the major cross-bedded part is overlain by a more pelitic and probably plane laminar graded part. The paleocurrent direction in the planar types is mostly from the south. Furthermore, wave ripple lamination is rather common (Fig. 9).

As a whole, this facies represents products of traction transportation. Taking into consideration its intervening position between the turbiditic facies (facies 1 and 2) below and the more coastal facies (facies 4, and the AvF) above and following Walther's law, it is logical to suppose that this facies was deposited on the outer-inner shelf. In the Suksiharju area this and facies 2 alternate in such a way that at least three members of each of the facies are represented. Due to the lack of continuous sections it is not possible to measure the thicknesses and the actual numbers of the members, but the thicknesses of each are some tens of metres at least. The contacts between the members are rather sharp indicating that transition from the turbiditic sedimentation to trac- 
tion transportation was rapid and repeated. In other words, the depth of water fluctuated rather rapidly, but during each cycle sedimentation conditions were rather stable as is indicated by the fact that, excluding the narrow contact zones, each member consists solely of either facies 2 or 3. There are three possible alternatives, at least, to explain this rapid change of water depth: 1) tectonic block movements along the continental margin 2) eustatic water level changes caused, for instance, by glaciations and deglaciations or by global tectonism, or 3) lateral wandering of the deposenter(s). Because the exposures are so few the choice between these alternatives cannot made at this stage.

Facies 4: Cross-bedded sands: The uppermost 100-200 metres of the $\mathrm{PjF}$ contain arkositic or feldspar quartzite interbeds whose thickness and amount increases towards the overlying AvF. The rocks are frequently trough cross-bedded and the set thickness is mostly about half a metre or more. Consequently this facies 4 represents sands transported by traction in a sedimentary environment which was between facies 3 and the AvF whose major lower part can be considered to consist of this same facies 4 .

\section{The Akanvaara Formation $(A v F)$ and the Kettukallio-type quartzites of the West Puolanka Paragneiss}

The feldspar-rich and frequently cross-bedded quartzites (Fig. 10) overlying the PjF in the eastern flank of the Puolanka anticline are mapped as the Akanvaara Formation ( $\mathrm{AvF})$. This formation is most typical at Central Puolanka where it forms a $\mathrm{N}-\mathrm{S}$ trending range running from Murtiovaara and Pieni Murtiovaara in the south via Akanvaara, the type locality, Ahvenvaara, Aittovaara, Kuorevaara, Murtovaara and Pärekangas to Askankangas in the north where the formation is cut tectonically by the Auho Fault Zone. Southwards from Murtiovaara this central range is not exposed until Rahikkalanvaara and Kumpuvaara, east of Kongasjärvi, wherefrom it

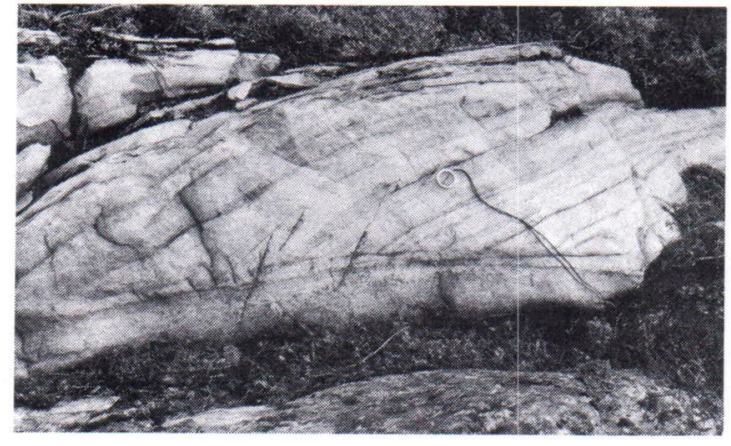

Fig. 10. Overturned, cross-bedded feldspar quartzite of the $\mathrm{AvF}$ at Suojoenkangas. Photo K. Laajoki.

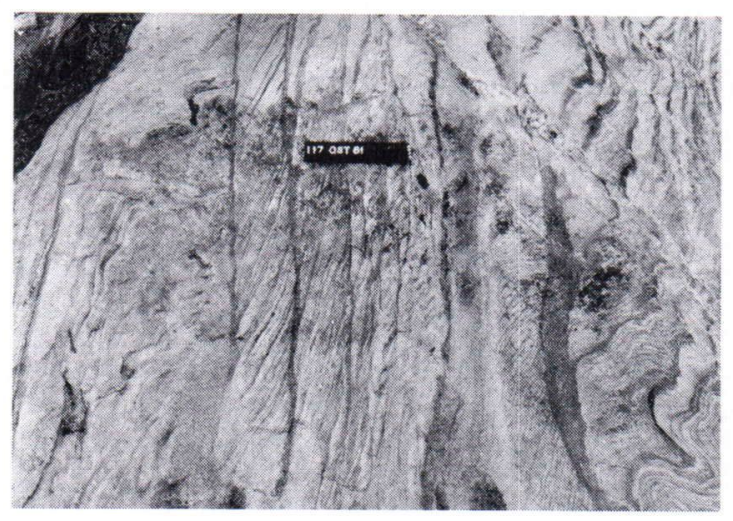

Fig. 11. Highly deformed cross-bedded quartzite at Mustikkavaara. Two cross-bedded sets are visible under and left of the label (16 cm long). Photo K. Laajoki.

continues via highly gneissic and migmatized exposures to the surroundings of Kivesvaara at Paltamo. So, this major central, relatively little metamorphosed range is at least $90 \mathrm{~km}$ long. Its thickness at Puolanka is at least $800-1000 \mathrm{~m}$. To the east, the AvF is interpreted as occupying a few exposures in the area from Eskosenvaara to Liejeenkangas. This area is, however, so poorly exposed and so strongly deformed that this interpretation deserves cautionary observation.

In addition to the banded feldspar and mica gneisses the WPP is also characterized by quartzites or quartzite gneisses. These are mostly light brownish or pinkish, feldspar quartzites or light sericite quartzites or even orthoquartzites called collectively the Kettukallio-type quartzites. They 
have been folded isoclinally and refolded at least twice and do not in general show any primary structures except transposed bedding. Locally, e.g. at Mustikkavaara, they show abundant deformed cross-bedding (Fig. 11) and other features which suggest strongly that they represent the western extension of the same quartzite lithology whose less metamorphosed part is visible as the AvF or, in terms of structural geology, the Kettukallio-type quartzites represent the more western extension of the AvF folded into the WPP. Consequently, they are classified metamorphically and structurally into the WPP but lithostratigraphically they or at least most of them could be correlated with the AvF.

The bulk of the lower and middle 500 metres of the AvF at Central Puolanka consists of light brownish or pinkish feldspar-quartzite showing abundant cross-bedding mainly of medium size and of through type (Fig. 10). However, planar cross-bedding is also fairly common. The lowermost parts close to the $\mathrm{PjF}$ contain micaceous interbeds whose amount, however, decreases drastically upwards while the feldspar contact sinks gradually in the quartzite. The uppermost 200-300 metres consist of light sericite quartzite or orthoquartzite showing rather low-angle crossbedding.

As a whole, the $\mathrm{AvF}$ is a rather monotonous sand unit containing only a small proportion of silt and clay fractions in its lower parts. Its maturity increases and grain size decreases a little upwards. As to its origin, the AvF may represent sands deposited on a shelf or in a delta. In any case it is evident that these sands were deposited in relatively shallow water and that they prograded upon the $\mathrm{PjF}$.

\section{The Pärekangas Formation (PkF)}

The area weast of the central range of the $\mathrm{AvF}$ is poorly exposed. At Pärekangas, in the north, a section mostly of phyllites and at least $500 \mathrm{~m}$ thick overlies the AvF. The same rocks are encountered in a few small exposures north of

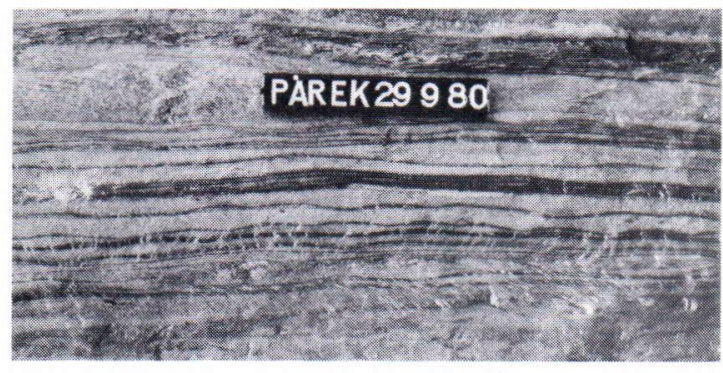

Fig. 12. Wavy bedding in a PkF metasemipelite at Pärekangas. Photo K. Laajoki. Label $16 \mathrm{~cm}$.

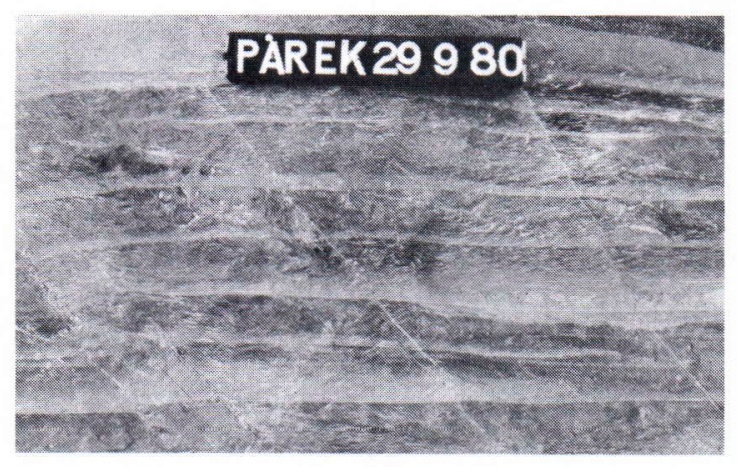

Fig. 13. Graded bedding in a PkF phyllite at Pärekangas. Photo K. Laajoki. Label $16 \mathrm{~cm}$.

Pärekangas and east of Puolanka church. It is quite probable that this Pärekangas Formation (PkF) forms a continuous $\mathrm{N}-\mathrm{S}$ trending metasedimentary unit at least $1000 \mathrm{~m}$ thick running from Askanjärvi in the north via the lakes of Vilpusjärvi and Somerjärvi to Osmankajärvi and Kivesvaara in the south. This area is, however, almost completely covered by glacial deposits.

At Pärekangas, the PkF overlies the AvF conformably. The change from the AvF to the $\mathrm{PkF}$ takes place abruptly. The lowermost $\mathrm{PkF}$ rocks are mostly phyllites or metasemipelites of varied lithologies showing wavy bedding, ripple marks and graded bedding (Figs. 12 and 13). Some cross-bedded quartzite interbeds and members a few metres thick are encountered locally. The metasediments east of Puolanka church are of the same type but they are more intensely deformed. Here, in addition to metasediments, the $\mathrm{PkF}$ also contains metalapillituffs. The metatuff 
contains lapillea of diabases and related rocks in a basic or intermediate matrix rock. Minor occurrences of intermediate or acid metatuffites or metatuffs are also found with which rocks in the road-cut of Kivesvaara, Paltamo, may be a correlative counterpart.

On the basis of its varied lithology and the primary structures shown by the metapelites it is concluded that the $\mathrm{PkF}$ represents tidal muds and sands deposited on the shallow water sands of the AvF.

\section{The upper contact of the CPG}

The upper contact of the uppermost formation, the PkF, of the CPG is not directly exposed anywhere. However, the Mäntykangastype conglomerates which start the next Karelian sequence, the East Puolanka Group, at Puolanka have derived their phenoclasts predominantly from the PkF and the AvF (Fig. 14). This, as well as the Kivesvaara conglomerate at Paltamo (Heino 1983), indicate that the deposition of the CPG was followed by a period of major erosion. Due to the lack of exposures it is not possible to say whether the CPG was also folded before the deposition of the next cycle. In any case, the upper contact of the CPG is erosional.

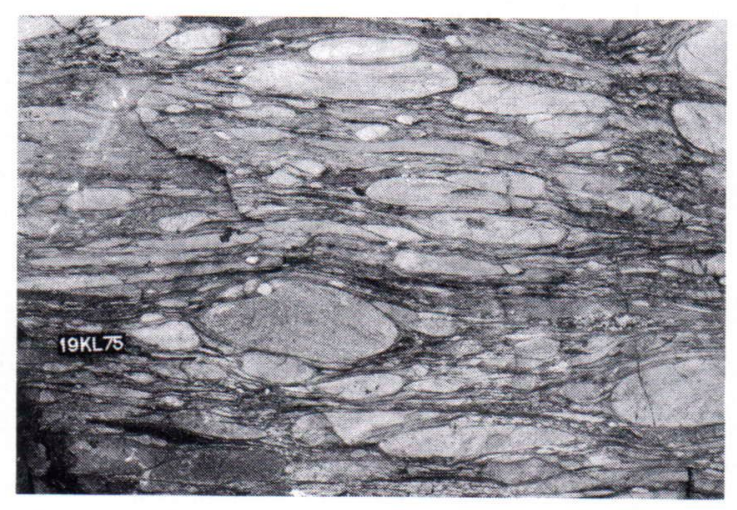

Fig. 14. A Mäntykangas-type conglomerate at Mustavaara, east of Roninkangas. The phenoclasts are mainly feldspar quartzites derived from the AvF. Photo K. Laajoki. Label is $16 \mathrm{~cm}$ long.

\section{Paleosedimentological conclusions}

The description above shows that the CPG represents a regressive sequence which starts with turbiditic sediments (the KeP and the lower and middle part of the PjF) and ends with tidal sediments $(\mathrm{PkF})$ with shelf and/or deltaic/coastal sands $(\mathrm{AvF})$ in between (Table 1). The sporadic paleocurrent observations indicate that the transportation was mainly somewhere from the south during the deposition of the $\mathrm{PjF}$ and $\mathrm{AvF}$.

Because the basement of the CPG is not known its tectonosedimentary significance is hard to established. However, taking into consideration the whole evolution of the Karelian formations in Kainuu it seems logical that the CPG could represent the narrow sea stage of the Proterozoic Wilson cycle followed by at least two transgressions (the Jatuli-type sequences) of the open sea stage (Laajoki in print).

\section{The age of the CPG}

The quartzite of Kettukallio contains a banded amphibolite bed whose zircon gives an age of 2540 Ma (O. Kouvo, pers. comm., 1983). Unfortunately, due to metamorphism it is not possible to tell the origin of this interbed. There seems to be two possibilities: the rock is either a metatuff or a metatuffite. If the former case holds, the age of the deposition of the Kettukallio quartzite would be about, or at least, $2540 \mathrm{Ma}$. In the latter case the deposition of the Kettukallio quartzite should date from less than $2540 \mathrm{Ma}$. The quartzite is intruded by a metadiabase of an age of $2276 \mathrm{Ma}$ (O. Kouvo, pers. comm., 1983).

The $\mathrm{PjF}$ is intruded by a metagabbro whose zircon is about 2113-2249 Ma old. A metadiabase is intruded into the contact between the $\mathrm{PkF}$ and the overlying Mäntykangas-type conglomerate at Mustavaara and Niskankangas. The age of the zircons are at least $2200 \mathrm{Ma}$ and $2138 \mathrm{Ma}$, respectively (O. Kouvo, pers. comm., 1983).

To conclude, the deposition of the CPG took place at least $2200 \mathrm{Ma}$ ago and it may even have started before $2540 \mathrm{Ma}$ ago. 


\section{Regional correlations}

In Kainuu the CPG and its metamorphic derivatives, the WPP, occupy the area west of the Kainuu Schist Belt measuring at least 100 and $10-20 \mathrm{~km}$ in north-south and east-west directions, respectively (Fig. 1). Preliminary mapping indicates, however, that the WPP may continue to the north as far as Koillismaa and to the south probably as far as Pielavesi (cf. Laajoki 1980 b, p. 13).

The gross lithology and the overall lithostratigraphic position of the CPG bears many similarities with some Lapponian rocks in Finnish Lapland; e.g. the Oraniemi area (Saverikko 1977). It is tempting to correlate these two major metasedimentary-volcanic units with each other; at least chronostratigraphically. However, to verify this more mapping and geochronological work are needed.

One of the greatest problems in Kainuu is how to correlate the western and eastern margins of the Kainuu Schist Belt. Recent works by Koistinen (1981), Park and Bowes (1983) and Laajoki (e.g. 1980 a) indicate strongly that the Karelian formations can probably no longer be considered as a single lithostratigraphic entirety, but that the tectonic zone running north south from North Karelia to Kainuu and further to Koillismaa may divide them into two major sub-units, called the western and eastern Karelides. The CPG forms the lowermost part of the former unit in Kainuu and so there may be no sense or reason to try to correlate it lithostratigraphically with the lowermost formations of the eastern margin of the Kainuu Schist Belt. On the other hand, it may be possible that there are some connections between those two margins. For instance the turbidites of the $\mathrm{PjF}$ may represent redeposited sediments deposited originally in the east.

\section{The significance of the CPG}

The recognition of the CPG has the following fundamental lithostratigraphical and palaeosedimentological consequences.

1. The traditional Jatuli-type sequences are underlain by a regressive metasedimentary sequence at least $2500 \mathrm{~m}$ thick at the western margin of the Kainuu Schist Belt.

2. At least some of the gneisses of Otanmäki, Vuoreslahti, Näläntö and those between the church at Pielavesi and Lampaanjärvi may be a counterpart of the CPG.

3. The CPG sequence may be correlative at least chronostratigraphically with the Lapponi rocks in Lapland.

4. The CPG seems to represent products of the narrow sea stage of an ancient (Proterozoic) Atlantic-type continental margin.

Acknowledgements. The author thankfully acknowledges the assistance given by Mr. E. Korkiakoski, M.Sci., Mr. O. Taikina-aho, M.Sci., and Mr. R. Kangas, B.Sci. The maps were drawn by Mrs. Ellen Komulainen and the English of the manuscript was checked by Dr. Sheila Hicks. Dr. K. Meriläinen of the Geological Survey kindly read the manuscript. The paper is a contribution to IGCP project 160 and to research project 54 of the Academy of Finland.

\section{References}

Havola, M., 1981. Suomen geologinen kartta. Kallioperäkartta 1 : 100 000, Geological Map of Finland, PreQuaternary rocks. Lehti/Sheet 3433, Sotkamo. Geol. tutk.laitos. Geol. Surv. of Finland.

Heino, T., 1983. Kivesvaara bedrock section at Paltamo. Pp. 69-72 in Laajoki and Paakkola (eds.). Exogenic processes and related metallogeny in the Svecokarelian geosynclinal complex. Geol. Surv. Finl., Guide 11.

Henderson. J. B., 1972. Sedimentology of Archean turbidites at Yellowknife, Northwest Territories. Can. J. Earth Sci. 9: $882-902$.

Koistinen, T., 1981. Structural evolution of an early Proterozoic strata-bound Cu-Co-Zn deposit, Outokumpu, Finland. Transact. Royal Soc. Edinburg; Earth Sciences 72: $115-158$.

Korkiakoski, E., 1981. Puolangan stauroliittikiilleliuskemuodostuman litostratigrafia ja rakenne. (The lithostratigraphy and structure of the Staurolite-Mica Schist 
Formation at Puolanka.) Res Terrae, Ser. B. 2, 41 p. -, 1982. Puolangan stauroliittikiilleliuskemuodostuman petrografia ja fasiesanalyysi. (The petrography and facies analysis of the Staurolite-Mica Schist Formation at Puolanka.) Res Terrae, Ser. B. 3, 49 p.

Laajoki, K., 1973. On the geology of the South Puolanka area, Finland. Geol. Surv. Finland, Bull. 263. 54 p.

-, 1980 a. Outlines of the Precambrian geology of the North Puolanka area, Finland. Res Terrae, Ser. A. 1, 11 p.

—, 1980 b. Karjalaisten muodostumien alaosat Puolangan tutkimusten valossa. (The lowermost parts of the Karelian formations in the light of the studies at Puolanka.) Res Terrae, Ser. B. 1, 18 p.

-, in prep. The Precambrian geology of the North Puolanka area. Geol. Surv. Finland, Bull.

- , in print. The Precambrian supracrustal rocks of Finland and their tectono-exogenic evolution. Precambr. Res.

Laajoki, K. \& Korkiakoski, E., in prep. Primary sedimentary features and paleosedimentology of the Early Proterozoic Puolankajärvi Formation, northeastern Finland.

Laajoki, K. \& Saikkonen, R., 1977. On the geology and geochemistry of the Precambrian iron formations in Väyrylänkylä, South Puolanka area, Finland. Geol. Surv. Finland, Bull. 292, 137 p.

Laajoki, K., Tuisku, P. \& Korkiakoski, E., 1982. Puolangan stauroliittikiilleliuskemuodostuman metamorfoosi ja deformaatio. (Metamorphism and deformation of the Staurolite-Mica Schist Formation at Puolanka.) Res Terrae, Ser. B. 5: 43-80.

Meriläinen, K., 1977. Suomen geologinen kartta $1: 100$ 000, kallioperäkartta, lehti 3531-Jonku. Geological Map of
Finland 1 : 100 000, Pre-Quaternary rocks, sheet 3531Jonku. Geol. tutk.laitos/Geol. Surv. of Finland.

Mutti, E. \& Ricci Lucchi, F., 1978. Turbidites of the northern Apennines: introduction of facies analysis. Intern. Geol. Review 20: 125-166.

Park, A. F. \& Bowes, D. R., 1983. Basement-cover relationships during polyphase deformation in the Svecokarelides of the Kaavi district, eastern Finland. Transact. R. Soc. Edinburgh: Earth Sci. 74: 95-118.

Rastas, P., 1969. Jormuan emäksinen kompleksi. (The basic complex in Jormua.) Unpublished master's thesis, Department of Geology and Mineralogy, University of Turku.

Saverikko, M., 1977. Oraniemen liuskeiden kerrostumisjärjestys ja stratigrafinen sijainti Keski-Lapin liuskejaksossa. (The stratigraphic order and position of the Oraniemi schists in the Central Lapland Schist Belt.) Unpublished degree dissertation. Univ. Helsinki.

Taikina-aho, O., 1982. Puolangan lounaisen paragneissikompleksin kvartsiittiesiintymien litologia ja rakenne. (The lithology and structure of the quartzite occurrences of the South Western Paragneiss Complex at Puolanka.) Res Terrae, Ser. B. 4, 44 p.

Walker, R. B., 1967. Turbidite sedimentary structures and their relationship to proximal and distal depositional environments. J. Sed. Petrol. 37: 25-43.

Wilkman, W. W., 1924. Suomen geologinen yleiskartta General geological map of Finland, $1: 400$ 000, lehti/ sheet D4, Nurmes.

—, 1929. Suomen geologinen yleiskartta General geological map of Finland, 1 : 400 000, lehti/sheet C4, Kajaani. 